earnestly the question to give up entirely the cultivation of wheat. The only.conclusion to be made by the table would be that with an intermission of 30 to 40 years, a period of superabundance follows. Perhaps a careful study of the old records from 1748 to $175^{\circ}$ would give some evidence, if the fly has ever been obnoxious here before the war. It is a curious fact that such an intermission of the appearance of the Hessian fly has occurred just in that quarter of the century, during which the most ardent collector and student of the N. American Diptera-I may say the founder of the American Dipterology-was here. In fact, Baron Von Osten Sacken has never met here with this Hessian fly, which is not represented in his collection nor in Prof. Loew's, both now in the Museum in Cambridge.

Note.-As the paper was going through the press, I received two pairs of $C$. destructor from Prof. J. A. Cook, the first American specimens which have come to my hands. In comparing these with two pairs of C. secalina from Prussia and Hesse, I was astonished to find the American insects twice as large as the European ones, and almost entirely black. I think they look so different that the identity is perhaps not sure. But a larger series from both countries and a more detailed knowledge of Diptera than are at my command, would be needed to decide the question.

\title{
TWO NEW SPECIES OF EUPELMUS, WITH REMARKS UPON E. (ANTIGASTER) MIRABILIS, WALSH.
}

BY L. O. HOWARD, WASHINGTON.

Eupelmus Reduvi n. sp.-Female.-Average length of body 2.4 $\mathrm{mm}$. Average wing expanse $4.6 \mathrm{~mm}$. Head slightly wider than thorax, which is of equal width with abdomen. Antennæ sub-clavate, as long as thorax. Collar rather long, much narrowed in front and concave above. Anterior half of mesothoracic scutum convex; a broad, longitudinal depression posteriorly, the anterior corners of which are extended on in the parapsidal furrows. Scutellum small, much narrowed in front. Abdomen somewhat concave above, keeled below. Middle tibial spine stout, but not quite so long as first tarsal joint, which is much widened and has a double row of serrations on its inner edge; second tarsal joint also 
widened and doubly serrate, but not nearly so much so as the first. Head densely punctured. Scutum apparently smooth, in reality very slightly punctured. Scutellum more coarsely punctured than the head. Abdomen smooth. Color: Head dark metallic green; eyes dark brown; antennal scape light yellow brown, flagellum black with extremely short whitish pile; scutum dull metallic green, appearing coppery brown in most lights ; scutellum brilliant light metallic green; sides of the mesopectus yellowish; front legs yellowish brown, darker along the upper side, tarsal claw dark brown; middle legs the same, spine light yellow-brown, serrated edge of first two tarsal joints nearly black; hind legs all dark brown, lighter underneath. Front wing with a quite well-defined, dusky, transverse band, at the point where the sub-costal vein reaches the costa, and with another transverse band at the point where the stigma is given off, with its proximal border convex and well-defined, and its distal border shading gradually to a hyaline wing tip. Sub-costal vein reaches costa at one-third the wing length, and the stigma is given off at two-thirds.

Male.-Average length $1.5 \mathrm{~mm}$. Average wing expanse $3 \mathrm{~mm}$. Head of same width as thorax and much wider than abdomen. Antennæ rather slender, sub-cylindrical, attenuated at tips, somewhat hairy, as long as thorax. Collar normal. Parapsides of scutum distinctly separated. Scutellum so narrowed in front as to be pointed. Middle tibial spur nearly as long as first tarsal joint. Sub-costal vein reaches costa at twofifths the wing length and gives off stigma at three-fifths. Head with delicate transversely elongate punctures. Thorax with a delicate hexagonal sculpture and sparsely scattered pits, from each of which arises a short hair. Abdomen smooth. Color: Eyes and antennæ dark brown; head, prothorax and mesothoracic scutum dark metallic green; the rest of the thorax coppery brown; abdomen dark brown, nearly black, front legs uniform light yellow, except tarsal claw, which is brown; middle femora yellowish with a brown stripe along upper edge, tibiæ yellow with a brown annulation at distal end, spine yellow, first and second tarsal joints yellow, all others brown; hind femora brown, proximal half of tibiæ yellow, the remainder dark brown ; all coxæ yellow ; wings clear, subcostal nerve and stigma light brown.

Described from 3 f's, 4 o's, reared from the eggs of Reduvius novenarius. 
Eupelmus floridanus n. sp.-Male.-Length of body 2.I mm. Wing expanse 3. I mm. Body rather slender. Head large, slightly wider than thorax. Thorax and abdomen long and narrow; abdomen tapering from fifth segment to base. Antennæ thick, cylindrical, somewhat shorter than thorax. Collar short. Scutum large and prominent; parapsidal furrows obliterated. Face finely impressed with transversely elongate punctures; top of head rather coarsely punctured; thorax as with $\hat{\varepsilon} E$. reduvii; abdomen smooth. Color: Head and thorax metallic green, appearing golden or coppery in different lights; eyes reddish brown; antennæ and abdomen dark brown, nearly black ; front femora very light yellow, tibiæ light yellow with a brown patch above, tarsi fuscous, the last joint darker than the others; middle femora light yellow with a slight fuscous patch above, tibiæ dark brown, yellow at either end, tibial spine whitish, first three tarsal joints whitish, last two dark brown; posterior femora light yellow with a very broad dark brown annulation in the centre, femero-tibial joint brown, tibiæ dark brown with a light yellow distal end, tarsi whitish except last two joints, which are dark brown; all coxæ yellow, stigma and subcostal vein light brown.

Described from one $\hat{\delta}$ specimen bred from an unknown Tineid larva on orange, taken at Jacksonville, Fla., by Prof. Comstock.

EUPELMUS (ANTIGASTER) MIRABILIS, Walsh.-The rearing of a number of specimens of this interesting Chalcid from eggs of Microcentrum retinervis collected by Prof. Comstock at Jacksonville, Fla., has given me an opportunity to verify a suspicion which I have for some time entertained, namely, that there were no grounds for the founding of the genus Antigaster. A comparison of the specimens with Walsh's description shows the latter to be an excellent one ; but there is not a single structural character mentioned by him as belonging to this " anomalous" genus, but what belongs equally well to the old genus Eupelmus Dalm. As to the habit of elevating its abdomen which Walsh considered so particularly anomalous, it is such a well-known thing to European writers that its seeming absence in E. Geeri caused Ratzburg a momentary doubt as to this species being a Eupelmus (see Ichn. d. Forstins, iii., p. 199). In the allied genus Eusandalum Ratz., and possibly in other Eupelmide genera, the same thing is seen, but in a slighter degree. Prof. Riley seems to have suspected this when he says: (6th Mo. Rep., p. I62) "No other species is so curiously constructed for rolling backward into a perfect 
ball, unless it be some belonging to the very closely allied genus Eupelmus."

I happened to observe the process of copulation with E. mirabilis, which took place in the following way: The males issued a day or two before the females. The first morning that a female made her appearance I happened to be watching the breeding jar. Presently one of the males ran up to her and began stroking her antennæ, the antennae of the male opening and shutting laterally, while those of the female made the usual up and down motion. After this had continued for some minutes, the male ran around her and took an erect position at the posterior end of her body, so that the two insects were at nearly right angles to each other, the male being supported by his middle and hind legs, and the end of his abdomen being closely applied to that of the female. Coitus lasted 30 secs., when the male withdrew his bilobed penis, and, curiously enough, ran forward upon the thorax of the female and seemingly clawed her violently with all of his feet. He then jumped down and ran away. I saw the operation upon one other occasion, when it was performed in a precisely similar manner.

\section{ANNUAL MEETING OF THE ENTOMOLOGICAL SOCIETY OF ONTARIO.}

The annual meeting of the above Society was held, according to announcement, in the City of Hamilton, on the evening of Tuesday, the 28th of September, in the City Hall. A number of those especially interested in Entomology in various parts of the Province were present.

The report of the Council was read and adopted; also that of the Secretary-Treasurer, which showed a satisfactory state of the finances. The President then delivered his annual address, ${ }^{*}$ for which he received the thanks of the members present.

The election of officers was then proceeded with, which resulted as follows :-

President-Wm. Saunders, London.

Vice-President-Rev. C. I. S. Bethune, M. A., Port Hope.

* See page $\mathbf{1} 89$ in present number. 


\section{$2 \mathrm{BHL}$ Biodiversity Heritage Library}

Howard, L. O. 1880. "Two new species of |Eupelmus|, with remarks upon |E. (Antigaster) mirabilis|, Walsh." The Canadian entomologist 12, 207-210. https://doi.org/10.4039/Ent12207-10.

View This Item Online: https://www.biodiversitylibrary.org/item/22088

DOI: https://doi.org/10.4039/Ent12207-10

Permalink: https://www.biodiversitylibrary.org/partpdf/27283

\section{Holding Institution}

MBLWHOI Library

\section{Sponsored by}

MBLWHOI Library

\section{Copyright \& Reuse}

Copyright Status: NOT_IN_COPYRIGHT

This document was created from content at the Biodiversity Heritage Library, the world's largest open access digital library for biodiversity literature and archives. Visit BHL at https://www.biodiversitylibrary.org. 